\title{
A NEW SPECIES OF THE SPIDER GENUS XYSTICUS (ARANEAE: THOMISIDAE) FROM ARIZONA*
}

\author{
By J. H. Redner and C. D. Dondale \\ Research Institute, Research Branch, Canada Department of \\ Agriculture, Belleville, Ontario
}

The North American crab spiders are now comparatively well known taxonomically. This is particularly true of the species in the large genus $X y$ sticus, which has been twice revised continentally by Gertsch (1939, 1953) and treated in more regional works by Buckle and Redner (1964), Schick (1965), and Turnbull, et al. (1965). It seems probable that any additional new forms that will be discovered will be from remote parts of the continent or in sibling relationship with known species. Several species have, however, been described only from one sex.

The purpose of this paper is to describe a distinctive new species of Xysticus from the mountainous parts of Arizona. Its structure clearly places it in the locuples group of the apophysate division of the genus, and its range suggests it to be an inland endemic of the southwestern United States.

\section{Xysticus humilis sp. $\mathrm{n}$.}

(figs. $\mathrm{I}-5$ )

Male: Total length 3.45 and $3.16 \mathrm{~mm}$.; carapace $\mathrm{r} .88$ and $\mathrm{r} .68$ $\mathrm{mm}$. long and I.82 and I.59 mm. wide; femur II I.86 and r.68 mm. long (measurements made, respectively, on the holotype and a paratype). Carapace low and smoothly rounded from side to side, being little higher at level of legs II than at level of posterior eye row; front nearly vertical; surface with thin coat of short, stiff, recumbent setae; eye area and front set with several spiniform setae; orangeyellow in color, with indistinct pale $\mathbf{V}$ in front of dorsal groove, which is uncolored, and with thin black line at side margins. Both rows of eyes recurved; ocular quadrangle wider than long, slightly wider behind than in front; laterals larger than medians; posterior medians only slightly closer to each other than to posterior laterals. Legs pale yellowish, I and II slightly darker than III and IV and with orange-brown tibiae; femur I with 3-4 weak prolateral spiniforms, I-2 dorsals, o retrolaterals; tibia I with o-3 weak dorsal spiniforms, o prolaterals, 4 pairs of ventrals, o retrolaterals; tarsal claws

*Manuscript received by the editor January 3, 1966. 




3

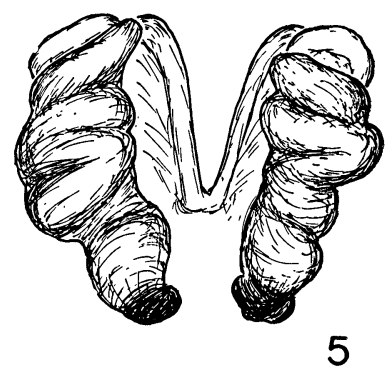

Redner and Dondale - Xysticus 
with 5 teeth. Abdominal dorsum pale yellowish to off-white, with pattern composed of thin lateral black lines on anterior half and 4-5 similar transverse lines posteriorly.

Tibia of palpus with ventral apophysis flattened and bladelike, and bearing small basal lobe; distal tegular apophysis flattened; embolus not thickened at tip (Figs. 2, 4).

Female: Total length (allotype) $5.2 \mathrm{I} \mathrm{mm}$; carapace $2.6 \mathrm{I} \mathrm{mm}$. long and $2.46 \mathrm{~mm}$. wide; femur II $2.32 \mathrm{~mm}$. long. Structure and color essentially as in male, but femora I and II concolorous with other segments; abdominal pattern and carapace setation as in Figure $I$. Epigynum with deep atrium and paired atrial sclerites as in Figure 3 ; spermathecae as in Figure 5, each copulatory tube arising posteriorly and forming convoluted mass dorsal to anterior end of spermatheca.

Range: Arizona.

Type Locality: Holotype male and one paratype male from Portal, Cochise County, Arizona, July 19, I964, J. A. Woods and V. Roth collectors. Deposited in the American Museum of Natural History, New York.

Other Locality: Allotype female from 2 miles north of Rodeo, Arizona, June 12, 1957, Statham and Plimton collectors. Deposited in the American Museum of Natural History, New York.

Diagnosis: $X$. humilis most resembles $X$. bradti Gertsch, which is known only from males taken in the State of Chihuahua, and $X$. texanus Banks, a better-known species, from Nuevo Leon, Texas, Arizona, Colorado, and the southeastern United States. Both $X$. bradti and $X$. texanus are relatively small in size and weakly setaceous in carapace and legs. $X$. humilis is distinct from these and all other known species of Xysticus in its low, pale, smoothly-convex carapace, in its abdominal pattern of thin black lines, and in details of the external genitalia. The male palpus has a stout basal tegular apophysis with a small irregularity midway along its basal margin (Fig. 4), whereas in bradti and texanus this structure is slender and smoothly tapered. The distal tegular apophysis further differs from that of texanus in being flat and rounded in outline rather than slender and "heeled", while the epigynal atrium is nearly circular instead of broadened, and the atrial sclerites are approximately ovoid instead of elongate and slender.

\section{Explanation of Plate 21}

Figs. 1-5. Xysticus humilis sp. n. 1. Dorsal view of female. 2, 4. Male palpi. 3, 5. Female epigynum and spermathecae. 


\section{ACKNOWLEDGMents}

The specimens described in this paper were lent to us by Dr. W. J. Gertsch, American Museum of Natural History, New York, to whom we are sincerely thankful.

\section{Literature Cited}

BUCKLe, D. J. AND J. H. REDNER

1964. The nearctic species of the Xysticus labradorensis subgroup (Araneae: Thomisidae). Canad. Ent., 96: 1138-1142.

GerTsCh, W. J.

1939. A revision of the typical crab-spiders (Misumeninae) of America north of Mexico. Bull. Amer, Mus. Nat. Hist., 76: 277-442.

1953. The spider genera Xysticus, Coriarachne, and Oxyptila (Thomisidae, Misumeninae) in North America. Bull. Amer. Mus. Nat. Hist., 102 : 413-482.

Schick, R. X.

1965. The crab spiders of California (Araneida, Thomisidae). Bull. Amer. Mus. Nat. Hist., 129: 1-180.

Turnbull. A. L., C. D. Dondale and J. H. Redner

1965. The spider genus Xysticus C. L. Koch (Araneae: Thomisidae) in Canada. Canad. Ent., 97: 1233-1280. 

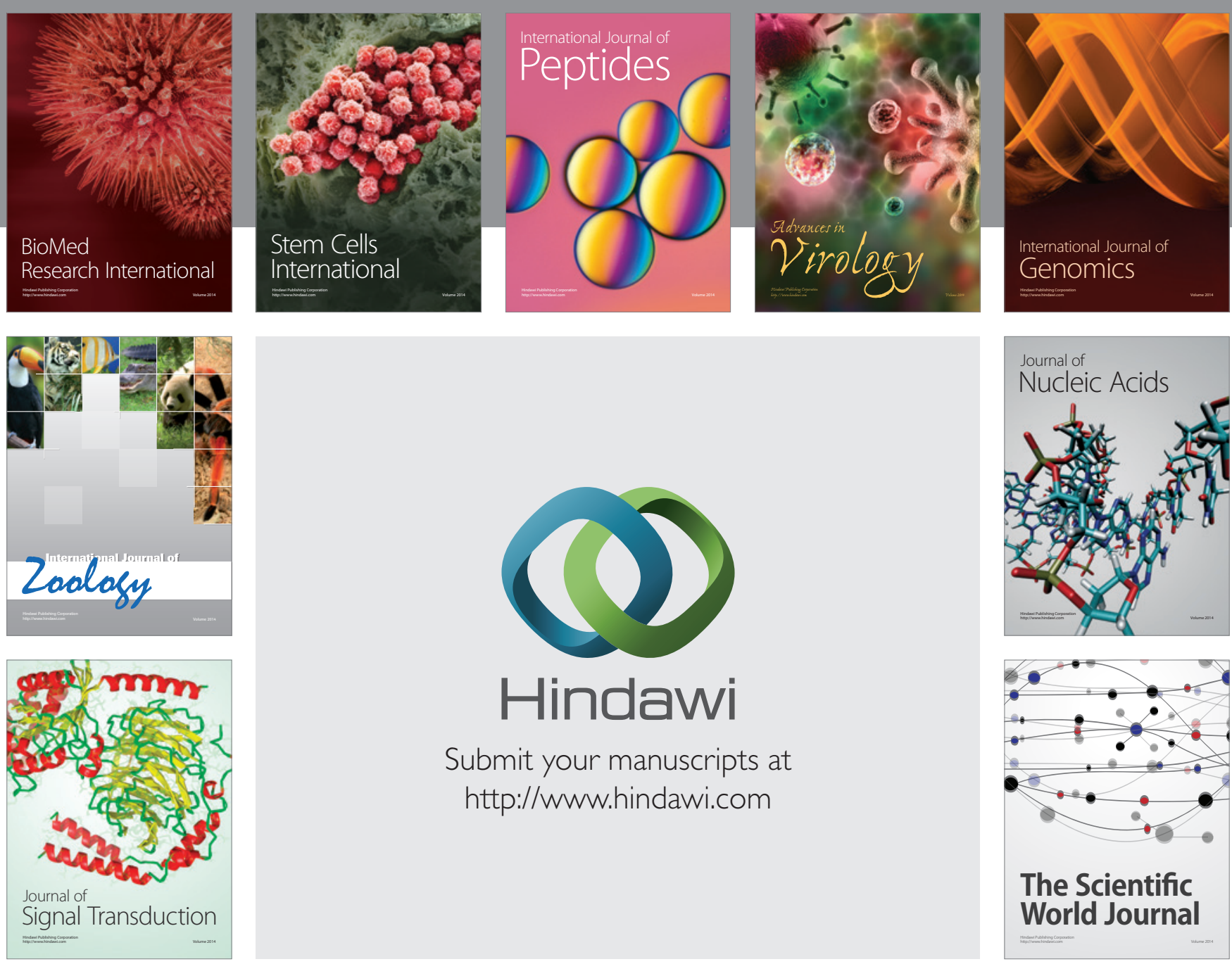

Submit your manuscripts at

http://www.hindawi.com
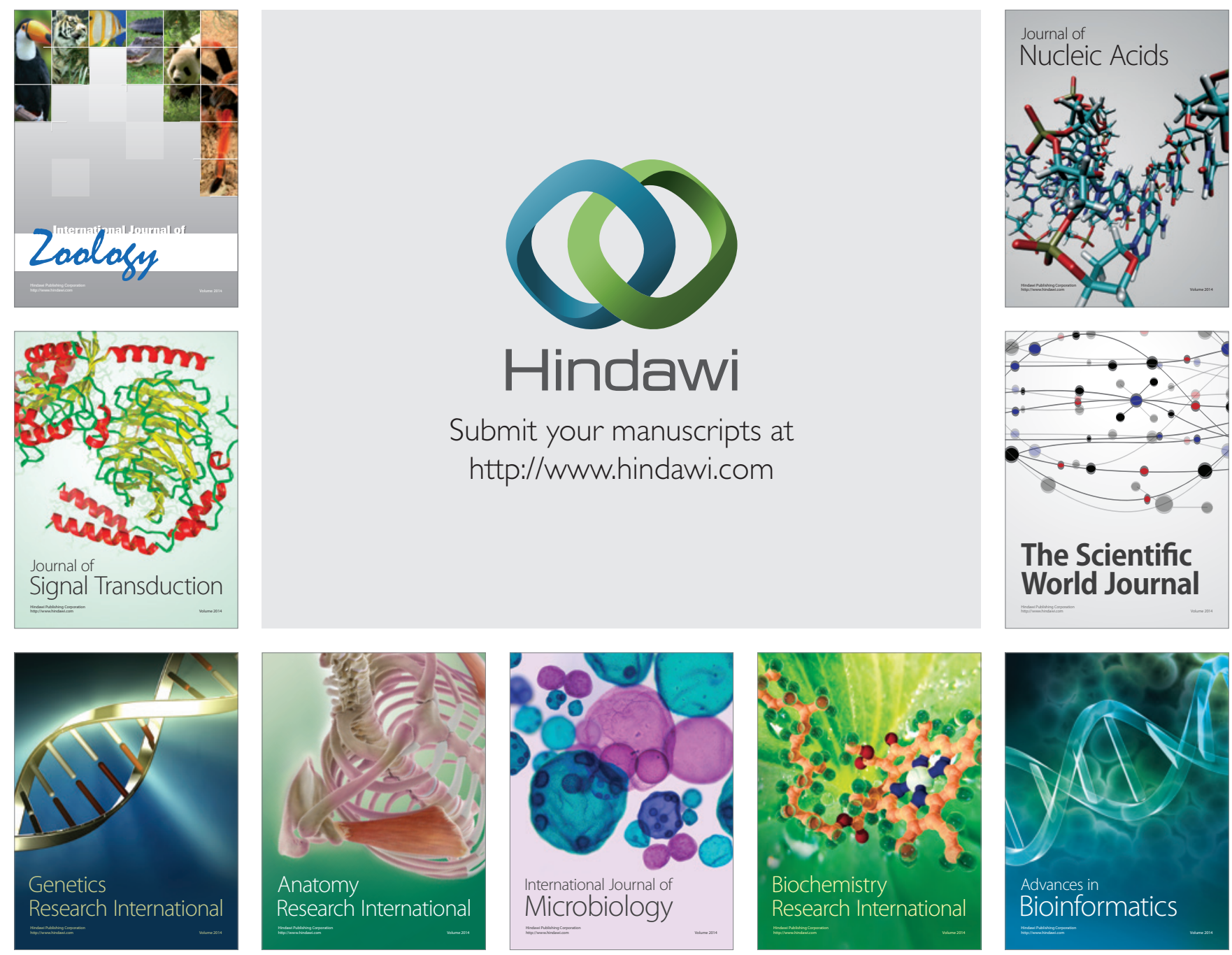

The Scientific World Journal
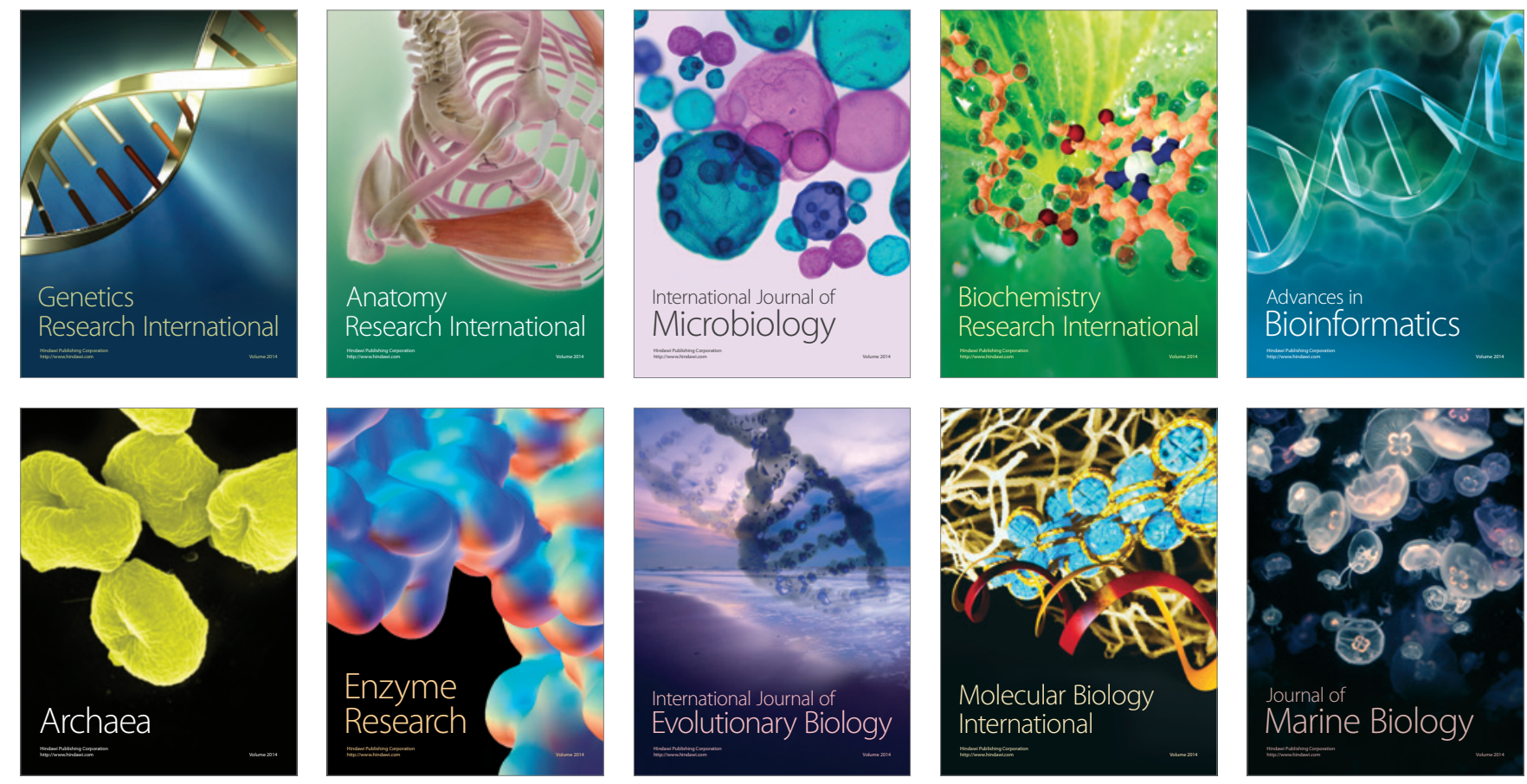